\title{
Morphological Characterizations of Two Populations of Feral Swine ${ }^{1}$
}

I. Lehr BRISBIN, Jr., Richard A. GEIGER, H. B. GRAVES 2 , John E. PINDER, III, James M. SWEENEY ${ }^{3}$ \& John R. SWEENEY ${ }^{4}$

\begin{abstract}
Brisbin I. L., Jr., Geiger R. A., Graves H. B., Pinder J. E. III, Sweeney J. M. \& Sweeney J. R., 1977: Morphological characterizations of two populations of feral swine. Acta theriol., 22, 4: 75-85 [With 2 Tables \& 1 Fig.].

Morphology of feral swine was compared between an island population $(O I P)$ and a mainland population $(S R P)$ in the southeastern United States. The two populations differed in the amount of time that they had existed in the feral state; OIP was essentially free from the influences of domestication for several hundred years, while SRP was feral approximately 20 years. SRP pigs were significantly heavier and had greater total body lengths than OIP pigs, but no significant differences in total body lengths or weights were noted between sexes within either population. A discriminant function analysis was used to test for significant differences between populations with respect to various body measurements, which were normalized for differences in total body length. Only shoulder height contributed a meaningful proportion of the total variation of the discriminant function for differences between populations. The discriminant function for differences due to sex within populations was not significant. Flank and spinal hair lengths were significantly greater in the OIP pigs, but exhibited no sexual dimorphism within either population. The frequency distribution of various color phenotypes was significantly different between populations, with differences largely attributable to a marked reduction in the frequency of the rarer phenotypes (particularly white) in the OIP.
\end{abstract} USA].

[Savannah River Ecol. Lab., Drawer E. Aiken, South Carolina 29801,

\section{INTRODUCTION}

With the continuing spread of man's civilization and agriculture, feral mammals have become increasingly important components of many biotic communities. However, the evolutionary and ecological importance of adjustments to a feral existence by escaped domestics are poorly

1 This study was conducted under the auspices of Project Genesis of the Ossabaw Island Project Foundation and was supported by contracts AT/38-1/ -310 and AT/38-1/-708 between the University of Georgia and the United States Energy Research and Development Administration. Present addresses: 2 Dept. Poultry Sci., Penn. State Univ., University Park, Pennsylvania, 16802, USA. 3 Dept. Forestry, Univ. Arkansas at Monticello, Monticello, Arkansas 71655, USA. ${ }^{4}$ Dept Entomol. Econom. Zool. Clemson Univ., Clemson, South Carolina, 29631, USA. 
known and little studied. Morphological characteristics of populations of feral mammals which have had differing developmental histories and which have been exposed to differing selective regimes may provide some clues as to the nature of the ecological and evolutionary adjustments that these populations are making in their new environment.

Feral swine (Sus scrofa Lin na e us, 1758) of the southeastern United States represent a potential resource for economic utilization in the form of meat harvest and recreational hunting, but in certain situations, they have also proven to be significant agents of ecological destruction and exploitation ( $\mathrm{H}$ ans on \& $\mathrm{K}$ arstad, 1959). The present study reports external morphological characteristics of two populations of feral swine which apparently have had quite different histories of establishment and exploitation and which have experienced different regimes of natural selection since reverting to a feral existence.

\section{METHODS}

Feral swine were collected from two populations. The Savannah River population (SRP) was sampled on the U. S. Energy Research and Development Administration's Savannah River Plant, located in Aiken and Barnwell Counties, South Carolina, U.S.A. The general features of the habitat of the Savannah River Plant and a brief history of its feral swine are presented by Jenkins \& Provost (1964). Briefly, the feral swine of the $S R P$ are mostly found in a $100 \mathrm{~km}^{2}$ area of undisturbed hardwood swamp forest which has heen closed to public access since 1952. Since that time, the population has been largely free from human disturbance or the further introduction of domestic animals.

The second population (OIP) was located on Ossabaw Island, Chatham County, Georgia, U.S.A., approximately $200 \mathrm{~km}$ to thi: southeast of the SRP study area. Ossabaw Island includes approximately $200 \mathrm{~km}^{2}$ of undisturbed habitat which consists primarily of oak-hammock forest and tidal salt marsh. Feral swine are known to have occurred on many of the coastal islands of Georgia for several hundred years ( $\mathrm{H}$ ans on \& Karstad, 1959) and the Ossabaw Island population $(O I P)$ probably has remained relatively free of human interference, although a limited number of domestic animals may have been introduced onto the Island during this period. Neither population, however, has shown any evidence that European wild hogs have been introduced as has occurred, for example, in certain populations of feral swine in California ( $\mathrm{P}$ in e \& G e r de s, 1973).

Swine on Ossabaw Island were captured either by hand or, in the case of larger individuals, with the use of trained hunting dogs. These animals were weighed, measured, tagged for subsequent identification, and released. Swine on the SRP, on the other hand, were either shot or captured in box traps and subsequently sacrificed prior to obtaining weights and measurements.

The following measurements were taken on each individual using procedures similar to those described by Lidvall et al. (1972): body weight (to the nearest $0.1 \mathrm{~kg}$ ), total length (along curve of spine, from tip of snout to base of tail), e a r length (from tip of ear to base of notch of external auditory meatus), snout length (from tip of snout to point midway between eyes), heart girth (body circumference, measured immediately posterior to forelegs), 
shoulder length (perpendicular distance from top of withers to tip of extended foreleg), hind foot length (from point of hock to tip of hoof), $\mathrm{ta}$ il le $\mathrm{ngth}$ (from base of tail to distal end of last caudal vertebra), spinal hair length (average length of hair at shoulder, mid-body, and hip along dorsal midline) and $\mathrm{fla} \mathrm{nk} h \mathrm{hir}$ le $\mathrm{gth}$ (average length of hair at shoulder, mid-body, and hip along midline of flank). All measurements were taken to the nearest $0.1 \mathrm{~cm}$.

A total of 133 pigs, 73 from the OIP and 60 from the SRP, was examined. However, these totals included juveniles and individuals for which certain measurements were not obtained. Therefore, in order to simplify the analyses of size, weight, and body proportions, subsets of 20 adult males and 20 adult females were selected randomly from each population and statistical analyses for these factors were based upon data from these 80 individuals. Sows that were lactating or in the later stages of pregnancy were eliminated from the analyses.

Color phenotypes of both populations were compared using data from all 133 pigs. In determining color phenotypes, the following classification was used (based largely on descriptions given by $\mathrm{Het}$ z e r, 1945): (1) black (solid black with no markings), (2) spotted (and combination of black and white spots, including all expressions of the partial-extension portion of the stortoise shell " or extension series of alleles and also the partial-extension pattern as seen in the Poland, China and Berkshire, but excluding the hampshire-banding pattern), (3) hampshire (black body with broad white band over shoulders), and (4) miscellaneous (including the reddish-brown or self red of the Tamworth and Duroc-Jersey resulting from a gene for a complete restriction of black; the dominant self white of the American, English, German, and Scandinavian white breeds and the slaty or dirty white of the Mangalitza; the blue and gray roans which usually appear in $F_{1}$ generations of crosses involving a gene for dilution of black; and the dark slaty brown agouti color typical of the wild European hog. Classification into one of these four color categories was based strictly on phenotypic expression and not on genotypic or allelic series.

Data for total body length, weight, and hair length were analyzed using a twoway analysis of variance procedure. This analysis permitted the identification of differences in means due to the effects of locality, sex, and the interaction of locality and sex. Comparisons of the relative sizes of various body measurements were made using a two-way multivariate analysis of variance and discriminant functions (M orris on, 1967; S e rvice, 1972). The following body measurements were used in these comparisons: ear length, tail length, snout length, shoulder height, and heart girth. All measurements except snout length were expressed as fractions of total body length. This transformation was necessary to make these variables independent of any differences that might occur in total body size. Snout length measurements were independent of differences of body size and did not require transformation. As will be discussed later, hind foot length could not be made independent of total length by any simple transformation and therefore was eliminated from this portion of the analysis. A chi-square contingency analysis was used to test for differences in the frequency of color phenotypes between the two populations.

\section{RESULTS AND DISCUSSION}

The means and confidence intervals for the total body lengths and weights of male and female pigs from both study populations are pre- 
sented in Table 1 . It was necessary to apply a natural logarithmic transformation to the data on total length and weight to achieve homogeneity of variance. Pigs from the $S R P$ were significantly longer than those from the OIP $(\mathrm{F}=47.59 ; \mathrm{df}=1.76 ; P<0.01)$, but there were no differences within either population due to $\operatorname{sex}(F=0.445 ; d f=1.76 ; P>0.05)$ or the interaction of locality and sex $(\mathrm{F}=0.606 ; \mathrm{df}=1.76 ; P>0.05) . S R P$ pigs were also heavier than those from the OIP $(\mathrm{F}=66.29 ; \mathrm{df}=1.76 ; P<0.01)$. Within populations, there were no significant differences in weight at:ributable to sex $(F=0.39 ; d f=1.76 ; P>0.05)$ nor were there any significant differences in weight due to the interaction of locality and sex $(F=228$; $\mathrm{df}=1.76 ; P>0.05)$. $S R P$ pigs averaged about $25 \%$ longer than OIP pigs and weighed about twice as much.

Since the lengths and weights of individual pigs were highly correlated $(r=0.92 ; \mathrm{df}=78 ; P<0.01)$, at least a portion of the differences in weizht

Table 1

Comparisons of total body length and weight and body hair lengths ${ }^{1}$ of two populations of feral swine. $95 \%$ C.I. - 95\% confidence interval.

\begin{tabular}{|c|c|c|c|c|c|c|c|c|}
\hline \multirow{2}{*}{ Locality } & \multirow{2}{*}{ Sex } & \multicolumn{3}{|c|}{ Total length, cm } & \multicolumn{2}{|c|}{ Weight, kg } & \multicolumn{2}{|c|}{ Avg. hair length cm } \\
\hline & & Number & Mean & $95 \%$ C.I & Mean & $95 \%$ C.I & Spinal & Flank \\
\hline Ossabaw & M & 20 & 95.8 & $88.8-102.8$ & 21.9 & $17.6-26.2$ & 6.8 & 4. \\
\hline Island & $\mathrm{F}$ & 20 & 96.3 & $89.1-103.5$ & 24.0 & $19.4-28.6$ & 6.2 & 3.7 \\
\hline $\begin{array}{l}\text { Savannah } \\
\text { River } \\
\text { Plant }\end{array}$ & $\begin{array}{l}\mathrm{M} \\
\mathrm{F}\end{array}$ & $\begin{array}{l}20 \\
20^{2}\end{array}$ & $\begin{array}{l}127.8 \\
121.0\end{array}$ & $\begin{array}{l}121.4-134.2 \\
111.4-132.4\end{array}$ & $\begin{array}{l}67.1 \\
55.3\end{array}$ & $\begin{array}{l}52.6-81.6 \\
40.1-70.5\end{array}$ & $\begin{array}{l}4.3 \\
5.0\end{array}$ & $\begin{array}{l}3.3 \\
3.5\end{array}$ \\
\hline
\end{tabular}

1 Hair length values were calculated as the averages of measurements tiken it the shoulder, mid-body, and hip, along the spinal and flank midlines, respectively.

2 Number $=12$ for hair length data.

between the populations might have been due to differences in length. Stated another way, it is possible that if the OIP pigs had been as long as the $S R P$ pigs, their body weights would have been similar. The relaive importances of the effects of length, locality, and sex on weight were analyzed using covariance procedures (Ste el \& Torrie, 1960; S c hef$f$ e, 1959). These statistical procedures are complicated by erroneous itatements in the literature, and some authors would argue that the covariance analysis between length and weight is invalid due to the demnstrated significant differences in length between the two populations. However, as Scheffe (1959) has shown, such a test is indeed valid although the information produced by the analysis differs from simple tests of hypotheses. If, in the covariance analyses, no significant effec of locality is observed, the length/weight relationships are probably identcal in each population. In such a case, all differences in weight due to lo- 
cality would be due to differences in body length. If, on the other hand, a significant locality effect can be demonstrated in such a covariance analysis, length/weight relationships in the two populations are not identical and the observed differences in weight are due, at least in part, to the effects of locality. The results of such a covariance analysis did, indeed, demonstrate such a locality effect $(F=12.76 ; d f=1.75 ; P<0.01)$ with no significant effect of $\operatorname{sex}(\mathrm{F}=0.01 ; \mathrm{df}=1.75 ; P>0.05)$. Thus, the $S R P$ pigs are of heavier body construction than OIP pigs, independent of simple differences in body length and sex between the populations.

Henry (1970) reported the lengths and weights of European wild hogs that were introduced into the mountains of eastern Tennessee in the early 1900's. The Tennessee and SRP pigs are of similar size, although the former are slightly longer and heavier. The Tennessee pigs, however, are much longer and heavier than pigs from the OIP. Data are not available to directly compare the Tennessee pigs with those of the SRP or OIP. However, the similarity of lengths and weights between Tennessee and $S R P$ pigs suggests that any differences between them would probably be substantially less than the differences described above for comparisons between $S R P$ and OIP pigs. Conjecture concerning the factors responsible for similarities or differences involving the Tennessee pigs, however, is complicated by the possibility that some of the pigs examined by Hen ry (1970) may have been penreared animals. Data from such individuals almost certainly would not be representative of the length/ weight characteristics of wild European hogs, and appropriate data from wild populations are needed to evaluate the extent to which the length/ weight relationships of either the OIP or SRP populations approximate those of their wild ancestor.

Sparse data presented from wild populations by $\mathrm{K} \mathrm{o} \mathrm{z} \mathrm{lo} \mathrm{(1968)} \mathrm{suggest}$ that European hogs are, on the average, heavier and larger than pigs from either the SRP or the OIP. Again, however, statistically valid comparisons cannot be made between data from the present study and these reported by Kozlo (1968). Ż u rowski et al. (1970) showed that increased body size and weight characterize $F_{1}$ and $F_{2}$ individuals resulting from crosses of European wild hogs with domestic sows of the "złotnicka pstra" breed. However, these increases in body size and weight could no longer be demonstrated statistically in the $F_{3}$ generation and thereafter. Although the introduction of such domestic crossbreds failed to produce long term changes in average body size or weight in the population of European wild hogs studied by these authors, noticeable increases did occur in the variability of body weight and certain body measurements within this population. The feral pigs of the SRP and, particularly, OIP thus appear to be among the smallest ever reported 
for the species, with the exception of certain breeds of domestic miniature swine which have been artificially selected to produce small body sizes.

The failure of either the SRP or OIP to exhibit significant sex differences in body length or weight is in striking contrast to the usual sexual dimorphism for such measurements exhibited by domestic swine (Ens$\mathrm{m}$ in ger, 1970). Henry (1970) reported that males of the Tennessee population of European wild hogs are larger than females after reaching an age of 14-18 months. In many cases, however, the normally accepted sexual dimorphism of such populations is based on data which has not been subjected to a critical statistical analysis. Perhaps the use of analyses such as those described in the present study would show that sexual dimorphism in length and weight of many such wild and domestic populations of swine are more apparent than real. After making such analyses, for example, Ż u rowski et al. (1970) failed to find statistically significant sex differences in body weights or in ratios of body length/height at the withers in their studies of European wild boar and wild boar $\times$ domestic sow crossbreds. It is also interesting to note that the larger size and weight of males, which supposedly typifies many domestic populations, are more apparent in the $S R P$, which has become feral more recently than they are in the OIP (Table 1).

The results of the two-way multivariate and discriminant function analysis for the proportional sizes of various body measurements are presented in Fig. 1. The discriminant function for locality was significant $(\mathrm{F}=4.05 ; \mathrm{df}=5.72 ; P<0.01)$, whereas the discriminant functions for sex and the interaction of sex and locality were not significant $(F=0.71$; $\mathrm{df}=5.72 ; P>0.05$, and $\mathrm{F}=1.12 ; \mathrm{df}=5.72 ; P>0.05$, respectively). This indicates differences in body proportions between populations but not between sexes within populations. In making these comparisons, the F-approximation of Hotelling-Lawley's Trace was used (S e r v i c e, 1972). As indicated in Fig. 1, there was a tendency for males of the two populations to show a greater divergence in body proportions than the females although, as mentioned above, the sex/locality interaction term of the multivariate analysis was not significant. This same tendency for males to show greater interpopulation differences than females was also apparent in the data for body length and weight (Table 1), although the sex/ locality interaction terms again were not significant. It is possible that an expanded study of larger numbers of individuals and more morphological measurements on each pig might demonstrate significant differences in such measurements for the sexes.

Only shoulder height, normalized for differences in total body length, contributed meaningfully to the total variability of the discriminant 
function for differences in locality, showing a positive correlation $(r=0.93)$ with the latter. The correlations of all other body measurements with the locality discriminant function were less pronounced $(r<0.25)$. In terms of actual body proportions, however, the differences in this measurement were relatively minor. The ratio of average shoulder height/average
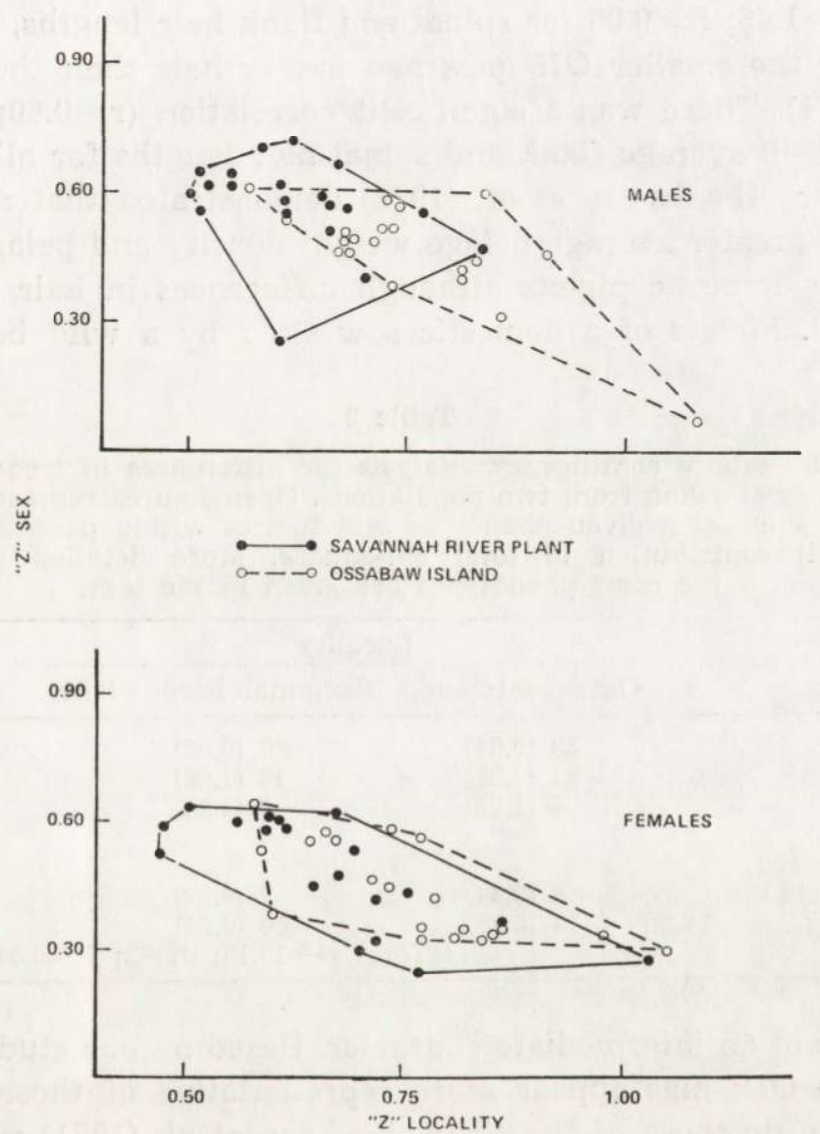

Fig. 1. Discriminant functions $(x \mathrm{Z} «)$ for differences due to locality of collection and sex of feral swine from two populations in the southeastern United States. The discriminant function for differences due to locality was statistically significant, while the ones for sex and the interaction of sex and locality were not. Separate figures are drawn for males and females for purposes of clarity of presentation.

total body length was 0.51 for the $S R P$ pigs, as compared to 0.54 for the OIP. As mentioned previously, differences between populations with respect to hind foot length simply reflect differences in total body length because hind foot length could not be made statistically independent of total body length. 
Comparisons of the hair lengths of pigs from the two study populations are presented in Table 1. Average hair lengths along the spine and flank failed to exhibit significant differences between sexes $(\mathrm{F}=0.03 ; \mathrm{df}=1.68$; $P>0.05$, and $F=0.25 ; \mathrm{df}=1.68 ; P>0.05$ for spinal and flank hair lengths, respectively). Both spinal and flank hair lengths did, however, show significant diferences between localities $(F=35.15 ; \mathrm{df}=1.68 ; P<0.01$, and $F=5.95 ; \mathrm{df}=1.68 ; P>0.05$ for spinal and flank hair lengths, respectively). In all cases, the smaller OIP pigs had longer hair than the larger SRP pigs (Table 1). There was a significant correlation $(r=0.60 ; \mathrm{df}=68 ; P<$ $<0.01$ ) between average flank and spinal hair lengths for all pigs considered together. $\mathrm{H}$ ans e n et al. (1972) demonstrated that neonatal wild piglets have greater average pelage weight density and pelage population density than domestic piglets although differences in hair lengths were not reported. Piglets of a domestic sow sired by a wild boar exhibited

Table 2

Results of a chi-square contingency analysis for differences in frequences of color phenotypes of feral swine from two populations. Open figures represent the number of individuals showing a given phenotype and figures within parentheses represent the within-cell contribution to total chi-square. More detailed descriptions of the color phenotypes are given in the text.

\begin{tabular}{|c|c|c|c|}
\hline \multirow{2}{*}{$\begin{array}{l}\text { Color } \\
\text { phenotype }\end{array}$} & \multicolumn{2}{|c|}{ Locality } & \multirow{2}{*}{ Totals } \\
\hline & Ossabaw Island & Savannah River Plant & \\
\hline Black & $38(0.04)$ & $29(0.05)$ & $67(0.09)$ \\
\hline Spotted & 31 (1.05) & $16(1.28)$ & $47(2.33)$ \\
\hline Hampshire & $4(1.02)$ & $8(1.23)$ & $12(2.25)$ \\
\hline \multirow{3}{*}{$\begin{array}{l}\text { Miscellaneous } \\
\text { (white, brown, red, } \\
\text { roan, agouti, etc.) } \\
\text { Totals }\end{array}$} & & & \\
\hline & $0(3.84)$ & $7(4.67)$ & 7 (8.52) \\
\hline & $73(5.95)$ & $\begin{array}{c}60(7.24) \\
\gamma^{2}=13.18 . d f=3\end{array}$ & $133(13.18)$ \\
\hline
\end{tabular}

pelage traits of an intermediate character. Based on our study, the pelage traits of the OIP pigs appear more representative of those of the wild ancestor than do those of the SRP. Fole y et al. (1971) suggested that the greater pelage density of wild piglets compared to domestic piglets provided a greater resistance to chilling, an obvious selective advantage in the feral state.

Comparisons of frequencies of color phenotypes in the two study populations are presented in Table 2. The black and spotted phenotypes were by far the most common in both populations, comprising 94.5 and $75.8 \%$ of the pigs in the OIP and $S R P$, respectively. A chi-square contingency analysis demonstrated significant differences in the frequencies of the various phenotypes in the two populations $\left(\chi^{2}=13.18 ; \mathrm{df}=3\right.$; $P<0.01$ ), with the greatest contribution to total chi-square being made 
by the relatively rare »miscellaneous « phenotypes (Table 2). A recalculation of the chi-square contingency analysis without the "miscellaneous « category showed no significant differences in color frequencies between populations $\left(\chi^{2}=4.26 ; \mathrm{df}=2 ; P>0.05\right)$.

The absence of some of these rarer phenotypes from the OIP, particularly the dominant self white, is even more striking when it is considered that a white domestic boar was released on Ossabaw Island for a period of 6-12 months, approximately 10 years ago (A. G r a v e s, pers. comm.). This dominant white gene apparently has failed to express itself in the island population. The absence of such miscellaneous color patterns in the OIP (Table 2) may suggest that genes producing these phenotypes were not present in the animals which originally founded the population or that these genes were eliminated by genetic drift or selection during the population's longer period of adjustment to a feral existence as compared to the $S R P$. Support for the latter hypothesis is contributed by $\mathrm{H}$ e t z e r (1945), who indicated that white pigs tend to suffer from sunscalding, a particularly severe problem for OIP pigs that feed regularly in open Spartina marshes. SRP pigs, on the other hand, spend more of their time in deeply shaded swamp habitats, and the white phenotype is more prevalent $(9.09 \%)$ in this population. The absence of such rare phenotypes from the OIP sample is not an artifact of sample size as evidenced by the fact that of a total of 419 pig sightings on Ossabaw Island, only $3.31 \%$ fell in the "miscellaneous " category. Of a total of 121 sightings of SRP pigs, however, $16.51 \%$ were of the "miscellaneous « type. Andrzejewski (1974) suggested that individuals which are heterozygous for recessive coat-color genes might be responsible for the maintenance of a recessive "spotty" coat-color mutation in European wild hogs.

It is presently impossible to identify the factors which have been responsible for the interpopulation morphological differences described above. In order to evaluate the relative importance of factor such as nutrition, disease, founder-effect, genetic drift, selection, and time of removal from domestication, additional information must be collected. Although reliable records of the morphological characteristics of the founding pigs of each population are not available, morphological comparisons of laboratory reared pigs from both populations could contribute important information concerning the role of disease and/or nutrition in producing size and weight differences comparable to those observed between the island and mainland populations. Information presented by $\dot{Z} \mathrm{urow}$ s k i et al. (1970), as discussed earlier, tend to minimize the importance of occasional introductions of domestic individuals into either population in terms of causing the observed interpopulation differences in average body 
size, weight, or body proportions. Some interpopulation diferences (such as frequencies of color phenotypes) might be more attributable to genetic factors than others (such as size and weight), which may be more respon. sive to differences in environmental factors such as disease, habitat cover. or food availability in the two study areas. W e a ve r \& In g r a m (1969), for example, demonstrated the striking morphological differences which can be produced in swine by simply rearing littermates at different environmental temperatures. Although it is tempting to speculate that the OIP pigs are showing greater progressive adjustments to a feral existence than those of the SRP, evidence for this is circumstantial. However, data presented here demonstrating interpopulation differences in hair length, sexual dimorphism, and frequencies of color phenotypes tend to support such a hypothesis.

Acknowledgements: Manuscript preparation was carried out with the help of Mrs. Candace Greene of the office staff of the Division of Biomedical and Environmental Research of the United States Energy and Research Development Administration and Mrs. Tonya Willing ham of the Savannah River Ecology Laboratory. We are grateful to the many participants in Ossabow Island's Project Genesis for their help in collecting and processing animals. Deserving of special thanks are Mrs. Clifford B. We st, Mr. and Mrs. Charles Wood, Philip F. C. Gree ar, Justin West, Brian Peck, David Williamson, Marc Bernard, Arthur and Eugene Graves and Roger and Tommy Parker. Mr. Paul Johns and personnel of the U.S. Forest Service at the ERDA Savannah River Plant similarly provided invaluable help in studying the mainland population. Douglas J ames, Zdzisław Pucek, Michael H. S mith and Donald Straney provided helpful comments of the manuscript.

\section{REFERENCES}

1. Andrzejewski R., 1974: Spotty mutation of the wild boar, Sus scrofa Lin$\mathrm{n}$ a e u s, 1758. Acta theriol., 19: 159-163.

2. Ensminger M. E., 1970: Swine Science. Interstate Publ.: 1-881. Danville, III.

3. Fole y C. W., S e erley R. W., Hansen W. J. \& Curtis S. E., 1971: Thermoregulatory responses to cold environment by neonatal wild and domestic piglets. J. Anim. Sci. 32: 926.

4. Hansen W. J., Fole y C. W., S e erley R. W. \& Curtis S. E., 1972: Pelage traits in neonatal wild, domestic and wcrossbred piglets. J. Anim. Sci., 34: $100-103$.

5. H a n s on R. P. \& Karsta d L., 1959: Feral swine in the southeastern United States. J. Wildl. Manage, 23: 64-74.

6. Henry V. G., 1970: Weights and body measurements of European wild hogs in Tennessee. J. Tenn. Acad. Sci., 45: 20-23.

7. Hetzer H. O., 1945: Inheritance of coat-color in swine I. General survey of major color variations in swine. J. Hered., 36: 121-128.

8. Jenkins J. H. \& Provost E. E., 1964: The population status of the larger vertebrates on the Atomic Energy Commission Savannah River Plant Site. Publ. TID-19562 of U. S. Energy Research and Development Admin.: 1-45. Wash., D. C.

9. Kozlo P. G., 1968: Ecological and morphological characteristics of Sus scrofa from the Belovezhskaya Virgin Forest. Vestn. Zool., 6: 53-58. 
10. Lidvall E. R., Ram sey C. B., Spears B. C. \& Fogleman H. G., 1972: Predicting carcass length of swine from live measurements. J. Anim. Sci., 35: 919-925.

11. Morris on D. F., 1967: Multivariate statistical methods. McGraw-Hill: 1-338. New York, New York.

12. Pine D. S. \& Gerdes G. L., 1973: Wild pigs in Monterey County, California. Calif. Fish and Game, 59: 126-137.

13. Scheffe H., 1959: The analysis of variance. John Wiley: $1-477$. London.

14. Service J., 1972: A user's guide to the statistical analysis system. North Carolina State Univ. Press: 1-260. Raleigh, North Carolina.

15. Steel R. G. \& Torrie J. H., 1960: Principles and procedures of statistics. McGraw-Hill: 1-481. New York, New York.

16. We aver M. E. \& Ingram D. L., 1969: Morphological changes in swine associated with environmental temperature. Ecology, 50: 710-713.

17. Zurowski W., Siudowa H. \& Gałka B., 1970: Effect of single pig's blood addition on the local wild boar (Sus scrofa) population. Trans. IX Internat. Congr. Game Biologists. Moscow.

Accepted, March 2, 1976.

I. Lehr BRISBIN, Jr., Richard A. GEIGER, H. B. GRAVES, John E. PINDER, III, James M. SWEENEY i John R. SWEENEY

\section{MORFOLOGICZNA CHARAKTERYSTYKA DWOCH POPULACJI DZIKIEJ SWINI}

\section{Streszczenie}

W południowo-wschodniej części Stanów Zjednoczonych przeprowadzono porównania wskaźników morfologicznych, takich jak: ciężar ciała, długość ciała, ucha, ryja, obwód klatki piersiowej, wysokość w kłębie, długość stopy, ogona, włosów na grzbiecie i na boku ciała w obrębie dwóch populacji - wyspowej i kontynentalnej - dzikich świń (Sus scrofa L in n a u s, 1758). Te dwie populacje powstały w różnych okresach; świnie żyjące na wyspie zdziczały przed kilkuset laty, podczas gdy populacja kontynentalna utworzyła się około 20 lat temu.

Zwierzęta $\mathrm{z}$ populacji kontynentalnej były istotnie cięższe i posiadały większe rozmiary ciała niż zwierzęta z populacji wyspowej (Tabela 1). Nie stwierdzono natomiast istotnych różnic rozmiarów i ciężaru ciała między płciami w obrębie obu populacji. Istotność różnic poszczególnych wskaźników między populacjami testowano przy pomocy analizy dyskryminacyjnej (Ryc. 1). Wyspowa populacja miała istotnie dłuższe włosy na grzbiecie i bokach ciała (Tabela 1) w porównaniu do świń z populacji kontynentalnej. Także rozkład częstotliwości występowania mutacji barwnych był w obu populacjach różny (Tabela 2). 